\title{
The performance of the brazilian economy: The development of inflation, growth and unemployment
}

\author{
André Cutrim Carvalho*1 / David Ferreira Carvalho \\ Federal University of Pará (UFPA) - Faculty of Economics (FACECON) - Brazil
}

Received: 16 January 2019 / Accepted: 26 April 2019

\begin{abstract}
In Brazil, as in most countries, government strategies have sought to encourage economic growth so as to reduce unemployment and maintain price stability as a deterrent to distributive conflict and rigid inflation, a historically difficult problem to solve in this country. Within this context, the fundamental objective of this article is to discuss the macroeconomic performance of the Brazilian economy during the period between the military dictatorship and the new republic, particularly in relation to inflation, economic growth and unemployment. The main conclusion is that Brazil urgently needs to improve its current economic performance. The federal government must therefore foster public and private investment so that all sectors of the economy may break with the current recession. It must also strengthen mechanisms to control inflation and reduce the risk factor and uncertainty for investors so that they are encouraged to hire labor. This will reduce unemployment and improve the outreach of social protection systems for low-income families. More expressly, it will generate opportunities for the improvement and specialization of certain productive activities so that the country is able to create skilled labor, thereby increasing income and stimulating consumption amongst these future workers.
\end{abstract}

\section{Keywords}

Macroeconomic performance / Brazilian economy / Inflation / Growth / Unemployment.

\section{0 desempeño da economía brasileira: o desenvolvemento da inflación, o crecemento e o desemprego}

\section{Resumo}

En Brasil, como na maioría dos países, as estratexias gobernamentais buscaron fomentar o crecemento económico para reducir o desemprego e manter a estabilidade de prezos como un elemento de control do conflito distributivo e a inflación, un problema historicamente difícil de resolver nese país. Neste contexto, o obxectivo fundamental deste artigo é debater sobre as magnitudes macroeconómicas da economía brasileira durante o período entre a ditadura militar e a nova república, especialmente en relación coa inflación, co crecemento económico e co desemprego. A principal conclusión é que Brasil necesita urxentemente mellorar o seu rendemento económico actual. Polo tanto, o Goberno federal debe fomentar o investimento público e privado para que todos os sectores da economía rompan coa recesión actual. Tamén debe reforzar os mecanismos para controlar a inflación e reducir o factor de risco e a incerteza para os investimentos e así incentivar a contratación de man de obra. Isto reducirá o desemprego e mellorará os sistemas de protección social para familias de baixos ingresos. Así, xeraranse oportunidades para a mellora e especialización de certas actividades produtivas de xeito que o país poida crear man de obra cualificada, aumentando así os ingresos e estimulando o consumo entre estes futuros traballadores.

\section{Palabras clave}

Desempeño macroeconómico / Economía brasileira / Inflación / Crecemento / Paro.

JEL Codes: E00, E24, E31, 040, 047.

\footnotetext{
* Corresponding author: andrecc83@gmail.com

1 The authors are grateful for all the valuable contributions, suggestions, and constructive criticisms received from all the anonymous peers.
} 


\section{Introduction}

In Brazil, the state has historically always been the social actor constitutionally responsible for economic policy, directing the development of judicious strategies basically to achieve three main objectives: to accelerate economic growth with a view to reducing the rate of unemployment, maintaining price stability as a deterrent to distributive conflict as well as inflation; to promote social mobility in terms of income distribution through investment policies in education and selective reduction of the excess tax burden; and therefore, to define appropriate public-private partnerships to finance investments in energy, transport and logistics infrastructure.

Thus, the state should intervene, whenever necessary, with fiscal, monetary and income policies to correct the existing market failures. Indeed, economic growth alone is insufficient to reduce all forms of inequality (sectoral, spatial and regional) due to the political and socioeconomic nature of the capitalist system. However, the distribution of income envisaged only through economic growth contains the seeds of its own destruction.

In the past, especially in the period 1969-1973, the Brazilian economy presented an extraordinary expansion, characterizing the phase of the so-called "Brazilian economic miracle". This term signifies a period of several consecutive years in which the country's economy, favored by a number of factors and circumstances, grew at an accelerated pace, with average annual rates of more than $10 \%$, while inflation was relatively low - an annual average of less than 20\%, according to Brum (2012).

However, as of 1973, economic growth began to decline and Brazil was plunged into a new recession, the main consequence of which was high unemployment rates. Hence, although the rate of economic growth was robust at the time of the "economic miracle", unfortunately there was no distribution of income, therefore, little poverty reduction.

Thus, the main objective of this article is to investigate the macroeconomic performance of the Brazilian economy, especially in the categories that demand a direct relation of causality, such as inflation, economic growth and unemployment.

\section{The performance of the brazilian economy}

The following section presents a macroeconomic analysis on the historical development of inflation, growth and unemployment in Brazil. In addition, the macroeconomic performance of the Brazilian economy during the period between the military dictatorship and the new republic will also be investigated, specifically the categories that demand an important causal relationship, such as inflation, economic growth and unemployment.

\subsection{The performance of the Brazilian economy 1964-1984: the military dictatorship}

Between 1964-1984, during which the military regime struck a blow against Brazil's fragile democracy, the team of bureaucrats who took charge of macroeconomic policy had already identified inflation as the main problem of the Brazilian economy. At the time, the diagnosis of stagnation and the poor external balance were considered, to a large extent, to be caused by the distortions and uncertainties resulting from the high inflation rates, which were linked to an imbalance of public accounts and permissive wage policy.

In such a context, the inflation of this period was diagnosed as an inflation of demand, although some cost inflation was also recognized, especially with regard to wages. In general terms, inflation and unemployment are two pathologies of concern to both the central bank and the federal government due to the adverse effects they project onto Brazilian society. Open unemployment is the result of an economic recession, or even of poor economic performance, and generally manifests itself through the social exclusion of a portion of a nation's active labor force. 
For this reason, unemployment is a very serious social problem, which needs to be tackled with public policies for social inclusion. On the other hand, inflation is a phenomenon that manifests itself by increased variations in the level of prices in an unremitting, persistent manner over a certain period of time.

The rate of inflation, given in percentage terms, is measured by the variation of the general price level (deflator) calculated by a reputable institution with sufficient technical competence to inform society of the behavior of the rate of inflation at any particular time. On the other hand, the unemployment rate, in percentage terms, is determined through the ratio of the total number of unemployed persons seeking employment during a certain period of time to the total number of those in the current active labor force of a country.

Thus, in the period corresponding to the initiation of the military regime, the period between 1964 and 1968, the stabilization program implemented at the time achieved a certain amount of success in reducing the rate of inflation from $100 \%$ in 1964 to something around $20 \%$ by 1969 . The Government's Economic Action Program (referred to as PAEG, in Brazil), drawn up by the Brazilian Ministry of Planning and Economic Coordination, listed amongst its objectives: i) to accelerate the pace of economic growth; (ii) to gradually contain the pace of inflation; (iii) to reduce sectoral and regional imbalances; (iv) to ensure an investment policy for the labor force that flowed onto the labor market, and (v) to correct the distortions that caused imbalances in the balance of payments.

A series of measures were put in place to achieve these objectives. The restrictive monetary and fiscal policies - under the leadership of Robert Campos and Octavio Bulhões - assisted by a rigid wage control policy, managed to reduce the government deficit of 4.2\% of the GDP (1964) to 1.1\% (1966). The cost of this orthodox stabilization policy was to create a gap between actual output and potential output - measured by the GDP trend line based on the historical rate of 7\% per year - which, according to Lago (1992), was only eliminated in 1973, ten years later in the "economic miracle" phase.

At the beginning of 1967 President Castelo Branco was succeeded by Costa e Silva, who died soon after and was replaced by a transitional military junta that, in turn, gave place to President Emílio Garrastazu Médici. Between 1968-1973, economic policy was under the command of Antonio Delfim Neto and João Paulo dos Reis Veloso. The Strategic Development Program (known as PED) defined an economic development policy, but kept inflation under control.

During this period, the real GDP grew at an average annual rate of $11.2 \%$, reaching a maximum of $14 \%$ in 1973, thus, well above the historical average rate of $7 \%$, as indicated by Lago (1992) and Singer (1977). Meanwhile, the average inflation rate of the period was $20.9 \%$ per year.

In 1973, the effects from the price rises of oil and derivatives were projected onto prices in the Brazilian economy. The following year, General Ernesto Geisel took over as president, and Mario Henrique Simonsen, as Minister of Finance and João Paulo do Reis Veloso as Minister of Planning and Coordination began to command economic policy of the period. The II National Development Plan (II PND) defined a national policy for economic development aimed at implementing certain segments of the heavy industry of capital goods, the petrochemical industry and the mining and metallurgical industries.

This ambitious national project to transform Brazil into a great economic power by the year 2000, however, adopted a strategy of financing the major projects of the II PND with resources from external sources. With the global economy in crisis, the rise in international interest rates ultimately had a detrimental effect on the intentions of the military government. From this viewpoint, Carneiro (1992) argues that concern was centered on paying the interest on the foreign debt, and with the high levels of Brazilian inflation, , and in the period 1974-1979, the average annual growth rate of the economy stood at $6.7 \%$ and the average annual inflation rate at $42.9 \%$.

In the 1980s, the federal government's macroeconomic policy turned exclusively to fighting inflation, and economic development was left behind. The low rates of economic growth during the 1980s characterize the lost decade. Between 1980-1984, General Figueiredo, the last president of the military regime, assumed the presidency amid an atmosphere of struggle, with a movement seeking the end of the military dictatorship and the implementation of democracy. 
Within this new context, as Carneiro \& Modiano (1992) observed, the secondoil shock in 1979 and the increase in international interest rates made the adjustment process of external accounts and the macroeconomic adjustment of domestic supply both more expensive and more prolonged from 1980 to1984. During this period, the average GDP growth rate was $2.0 \%$ per year and the average annual inflationwas $129.6 \%$.

\subsection{The performance of the Brazilian economy 1985-1989: the Governments of Sarney and Collor-Itamar}

With the unexpected death of the first president of the New Republic, Tancredo Neves, VicePresident José Sarney took over as president. The economic policy of the New Republic, set out to define, within an orthodox tradition, the main causes of Brazil's inflation, which were considered to be: the public deficit and the generous, albeit unbalanced, salary readjustment policy, due to the social commitments taken on by the new regime. Between March and September 1985, there was a substantial change in economic policy characterized by the recessionary adjustments imposed by the International Monetary Fund (IMF).However, there was a clear acceleration of inflation as of the last quarter of 1985, and inflation (IGP-DI) reached 235.1\%. In order to combat inflation, Minister Dornelles introduced a fiscal policy involving drastic cuts in government spending, alongside an increase in the tax burden and a monetary policy of issuing currency and placing public bonds onto the open market. On the other hand, according to Carneiro et al. (1986), Minister Sayad, from the Secriteriat of Planning and Economic Affairs (SEPLAN), determined that an important dimension of the public deficit was due to the financial burden of interest that both the treasury and the state was having to face.

The failure of the economic policy to combat inflation and the impasse between these two ministers led to Dornelles being replaced by Dílson Funaro as Minister of Finance, thereby initiating a new stage of economic policy. It began with a stabilization program, known as the Cruzado Plan, which identified that inflation was fueled by the indexing mechanism, thus it was insufficient to manipulate fiscal and monetary policies so as to promote price stability and economic growth.

Between 1985 and 1989, the three plans of the Sarney era produced no more than a temporary suppression of inflation, since the problems responsible for distributive conflicts had not been solved, as confirmed by Carneiro \& Buainain (1989).

During this period, the average annual rate of GDP growth stood at $4.4 \%$, the average annual inflation rate stood at $194.6 \%$ and the average annual unemployment rate at $6.7 \%$. Between 1985 and 1989, as demonstrated in Figure 1, the Brazilian economy revealed a change in the orientation of economic policy in relation to 1981-1984, characterized by macroeconomic adjustment and confronting the problems generated by the external debt.

When President Fernando Collor de Melo took over in 1990, he implemented his heterodox plan to combat inflation - the Collor Plan. The results of this stabilization plan were disastrous in terms of the credibility of the economic agents.

Following other heterodox ideas, the Collor Plan under the myth of an "accurate shot", ultimately lost credibility by seizing all private assets and for the poor results achieved in the Collor Plans I and II, including the political crisis that led to President Collor's impeachment in 1992 and the immediate investiture of his vice, Itamar Franco, as President of the Republic, according to Bresser-Pereira \& Nakano (1991).

In this period, the macroeconomic performance fell below expectations: the average annual rate of economic growth stood at $1.4 \%$, the annual rate of inflation at $298.7 \%$ and the unemployment rate at 8.4\%. President Itamar Franco invited Senator Fernando Henrique Cardoso (known as FHC) to the portfolio of the Ministry of Finance.

The basic idea to combat the high rate of inflation in Brazil was built on an understanding of the concept of currency, which is defined by its functions and its social acceptance. The state intervenes to transform the currency of high purchasing power into a forced currency, which requires a government 
decree to guarantee its value. However, the diagnosis of the economic team was that the problem of accelerating inflation was due to the nature of its inertial indexing.

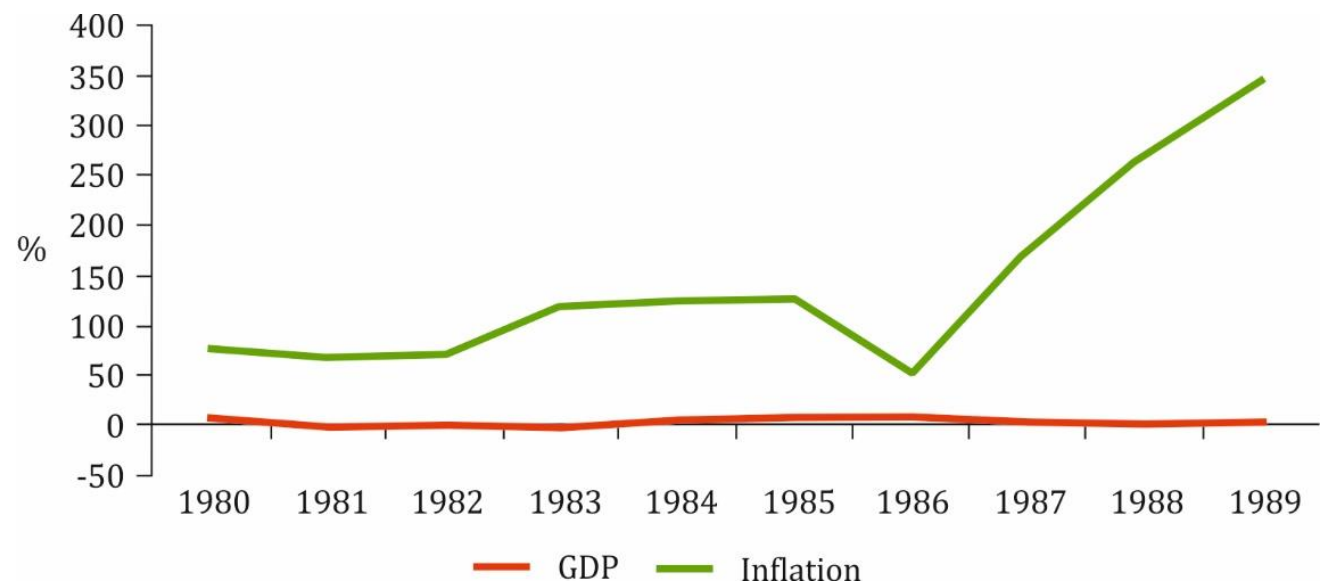

Figure 1. Evolution of GDP and Inflation in Brazil: 1985-1989. Source: Instituto Brasileiro de Geografia e Estatistica (IBGE)/IPEAdata.

In Basha's (1998) conception, the measure adopted, after precautions had been taken with the rigor of macroeconomic policies, was to reconstitute some of the functions of the currency through the creation of what was termed, the URV, i.e., the creation of a new unit of account anchored to the dollar. As Malan (1999) recalls, once this new unit of account had been accepted by society, the next step was to transform it into a forced currency, which was called the Real, and to put the plan into action as the Real Plan.

\subsection{The performance of the Brazilian economy 1995-2002: FHC and Lula}

The success of the Real Plan ensured the election of Fernando Henrique Cardoso (FHC) as president for the period 1995-1998. With the passing of time, the macroeconomic policy adopted to preserve the success obtained from the Real Plan proved to be incorrect. Indeed, the extravagant policy of opening up trade to prevent price adjustments on the supply side, by intensifying competition from domestic products with foreigners, eventually led to bankruptcy for a number of companies, who were unable to afford cheaper foreign products because of the appreciation of the Real against the dollar.

The restrictive monetary policy of raising interest rates scared away corporate investment spending and expenditures of household consumption, thereby resulting in low economic growth. Moreover, the preservation of a fixed exchange rate system, anchored to a high interest monetary policy, eventually attracted volatile capital to close the balance of payments with an inflow of liquid capital into the capital account.

In an environment of frenzied speculative attacks against the currencies of Mexico, Russia and some Asian countries, Brazil came into the limetlight for the 1998 attack on the Real, which led to the downfall of the Central Bank President, Gustavo Franco, who was replaced by the economist Francisco Lopes, and who, surprised by a powerful attack against the currency - the Real, decided to adopt a dirty float exchange rate system.

Nonetheless, Pinheiro, Giambiagi \& Gostkorzewicz (1999) argue that the problems of the external sector remained unsolved, especially regarding the deficit in the current account balance. Despite international strategic reserves, in a suicide operation, the country lost more than eight billion dollars. This loss led to Francisco Lopes being immediately replaced as President of the Central Bank by the economist, Armínio Fraga. 
Within this context, monetary policy was based on targeting inflation and controlling aggregate demand through high interest rates. In order to meet the government's spending commitments, the Ministry of Finance adopted a leonine policy of tax increases to cope with the growth of the public deficit.

After a second election, running against Luiz Inácio Lula da Silva, President Fernando Henrique Cardoso was re-elected for a second term from 1999-2002. During this period, the intention of the FHC Government was to conduct its privatization policy, the strategy of which was to reduce the role of the state in the economy. The "Avança Brasil" Plan defined a broad investment program of US\$ 119 billion for economic infrastructure and social sectors.

The forecast for the GDP growth was 4.5\% with an inflation of 3.5\% between 2000-2002. However, the results of the FHC Government were weak compared to the expectations in terms of economic performance between 1995-2002. During FHC's first term in office, between 1995 and 1998, the average annual GDP growth rate was just $2.1 \%$, the average annual inflation rate was $15.4 \%$, and the annual average unemployment rate was $11,6 \%$. In his second term of office, between 1999-2002, the average annual rate of GDP growth stood at $2.8 \%$, the annual average inflation rate at $5.9 \%$ and the annual average unemployment rate at $11.4 \%$, as demonstrated in Figure 2.

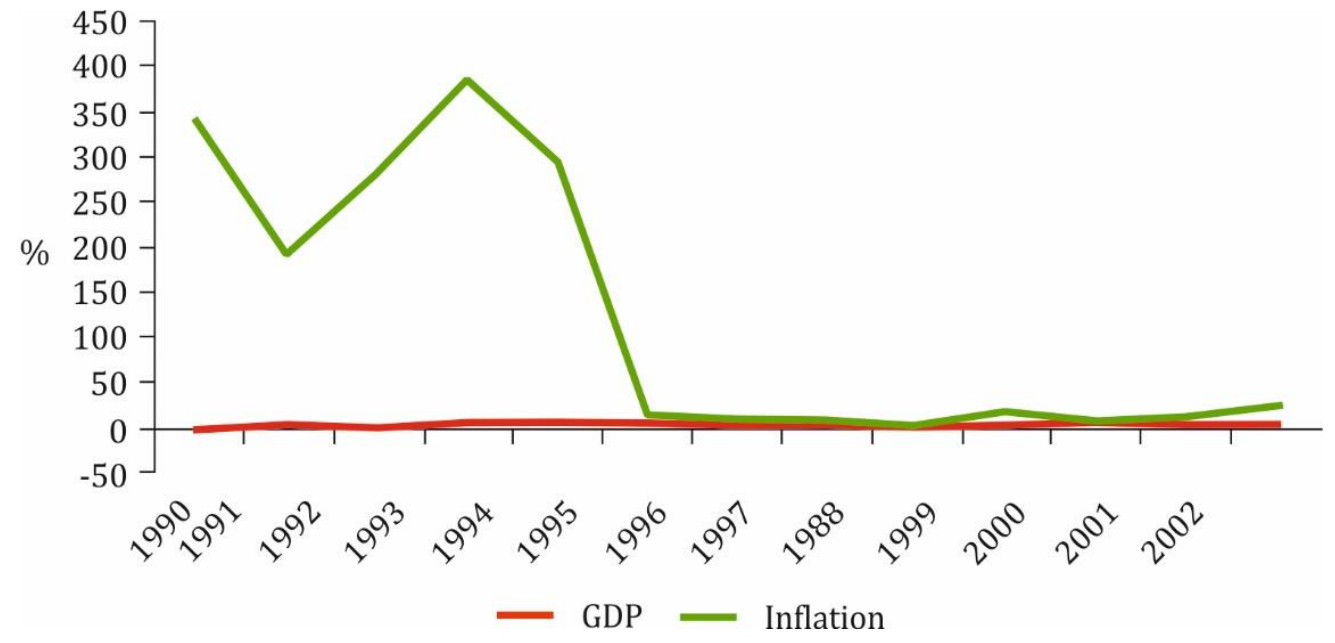

Figure 2 - Evolution of GDP and Inflation in Brazil: 1990-2002. Source: Instituto Brasileiro de Geografia e Estatistica (IBGE)/IPEAdata.

In 2002, however, with the election President Luiz Inácio Lula da Silva, despite certain apprehension regarding the direction of the previous government's macroeconomic policy, the previous government's macroeconimic policy was maintained, ensuring a smooth transition that ultimately contained the trend towards high inflation. The new government acknowledged that the economic performance in terms of Brazil's GDP had been very low over the previous two decades and needed to be overcome.

Indeed, the legacy left by the FHC government was the most serious unemployment crisis in Brazil's economic history, when unemployment reached levels of $10 \%$ per year, as confirmed in Figure 3. Therefore, the recovery of economic growth focused on minimizing the unemployment crisis, however, the foreign sector was displaced.

Nevertheless, although world trade grew 7\% per year between 1984 and 2002, Brazil's trade level with the rest of the world stood at $4.6 \%$ per year. Brazil's participation in the flow of international trade during the same period declined from $1.39 \%$ to $0.97 \%$ of total world trade. The following diagnosis, proffered by Minister Antonio Palocci Filho revealed the intention of the new Lula 
government regarding the direction of economic policy: "so that our country may once again return to sustainable growth over the next few years, we need to implement a development strategy strongly connected to trade, thereby increasing Brazil's share of world trade".

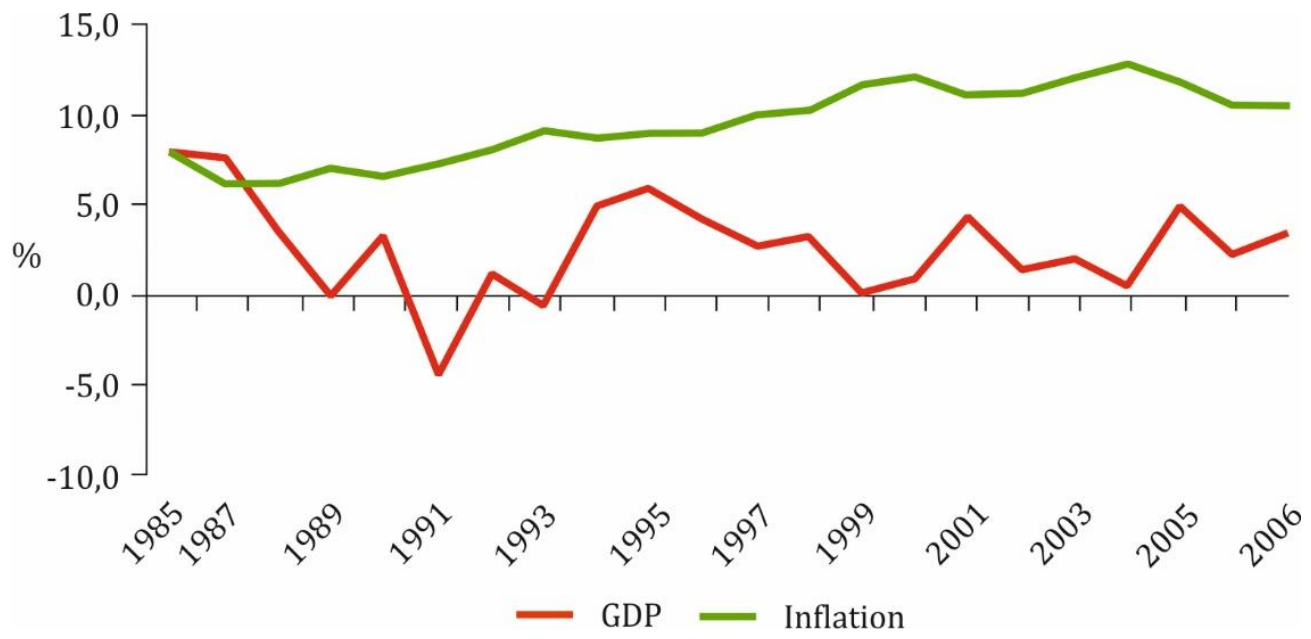

Figure 3. Evolution of GDP and Unemployment in Brazil: 1985-2006. Source: Instituto Brasileiro de Geografia e Estatistica (IBGE)/IPEAdata..

The economic development of Brazil was thus postponed, with a strong participation of the domestic market, leaving the tax, social security and political-party reforms until after. It is clear, therefore, that President Lula's government left aside economic development to concentrate on macroeconomic stability supported by a monetary policy with high interest rates. Congressional efforts to modernize the credit system and approve the bankruptcy laws was one of the few initiatives taken to reduce the high banking spreads and provide greater legal guarantees to contracts, aiming to reduce the costs of the loans, as observed in Mantega (2003). Meanwhile, the Central Bank opted for a strategy to move short-term adjusted inflation targets to force long-term inflation convergence.

However, despite the success achieved, the performance of the Brazilian economy continued to be unsatisfactory, compared to the performance of other similarly sized countries.

Despite the success obtained with the significant growth of net exports, Brazil's economic performance, between 2003 and 2006, was somewhat pitiful: the average annual GDP growth rate was $2.8 \%$, the average annual unemployment rate was $11.4 \%$ and the average annual inflation rate was $5.9 \%$. Figure 4 presents the inflation and unemployment rates for the period 1985-2006.

Over time, the policy of high interest rates became the main visible instrument for controlling inflation. This high interest policy became the main object of criticism by opposition economists and even economists from President Lula's own party. The focus of the debate was the perception of the opposition, that high interest rates were holding back economic growth because they would inhibit investment and consumption. In any case, the upward trend observed in the rate of inflation was contained by means of this monetary policy, albeit at a high social cost, manifested in high unemployment rates.

\section{Econometric models of inflation In Brazil: A brief understanding}

Carvalho \& Carvalho $(2018,2019)$ analyzed a number of approaches in order to explain inflation and present an estimation of econometric models for Brazil in 1995-2018. With the aid of structuralist, monetarist, and inertialist econometric models, the articles sought to understand the factors that 
influenced the inflation rate during this period, based on the monetarist models of rational and adaptive expectations.

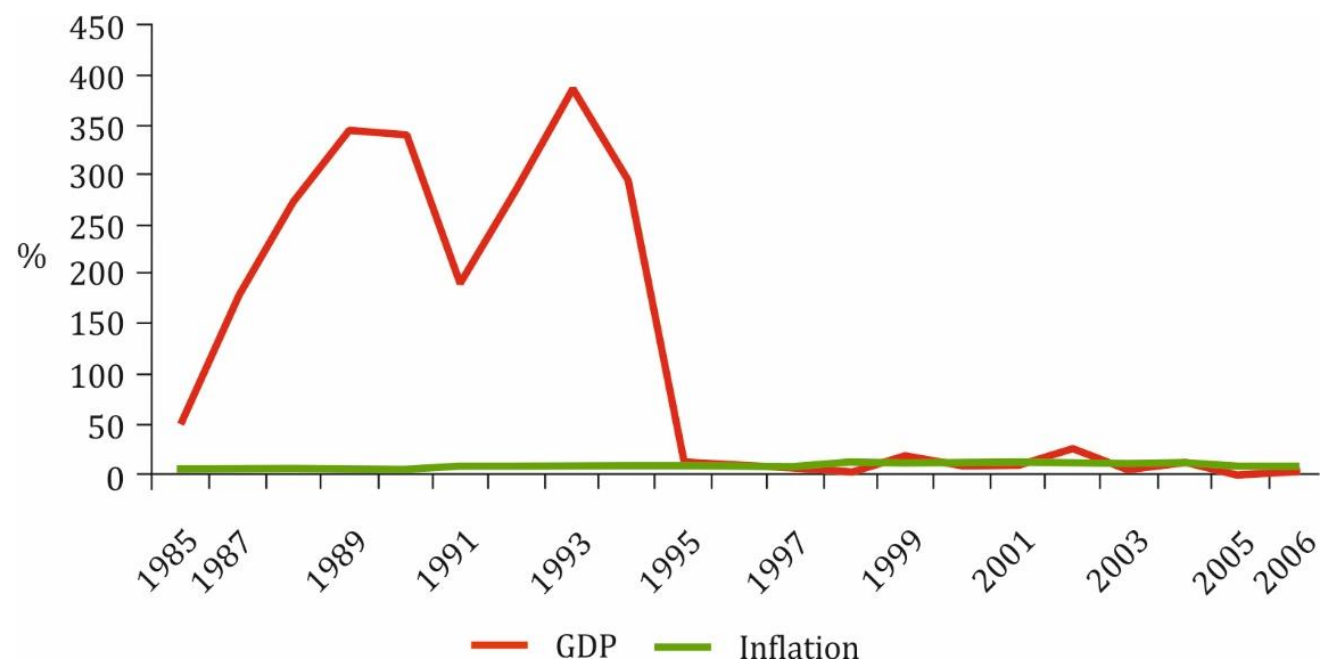

Figure 4. Evolution of inflation and unemployment in Brazil: 1985-2006. Source: Instituto Brasileiro de Geografia e Estatistica (IBGE)/IPEAdata.

Once the regressions were completed, the articles reached certain conclusions on the statistical significance level of the model and whether its variables had the power to explain the inflation rates in Brazil during the period following the Real Plan. The main point was that there were reasons to reject the hypothesis that the trend variable was adequately formulated to capture the effect of financial innovations in the equation for the demand for money.

Finally, the articles indicated that when the inflation rate increases, monetary policy reacts with an increase in the real interest rate. The impact of inflation on the real interest rate depends on the monetary policy rule of the central bank. In general, raising the interest rate alone is not able to reverse the rise in the rate of inflation if it is not accompanied by a fiscal policy of reducing public spending and/or raising tax revenue.

Although the control of inflation generally has apositive effect on the economy, its impact in fostering economic development is very limited if there is no increase in the capacity to produce and import raw materials and intermediate inputs, thereby enabling a sustainable increase of production. In the following section, we analyze the evolution of manufacturing and non-manufacturing real valueadded per capita in Brazil for the period 1995-2016.

\section{The positive effect of manufacturing and energy on economic development}

Figure 5 presents the evolution of real value-added per capita in the manufacturing and nonmanufacturing sectors.

According to Guisán \& Cardim-Barata (2003), Guisán (2017, 2019), as well as other sources, real value-added per capita of manufacturing is low in Brazil and it is therefore important to increase it, in order to foster economic development, because of its direct and indirect positive effects on other sectors. These positive effects contribute to the sustainable development of other sectors, particularly services, without an excessive increase in the external trade deficit. In 2016, the value of manufacturing was below 1,600 US\$ per capita, at 2011 prices and purchasing power parities and non-manufacturing was below 13,000. These values are clearly low. In Figure 5, we observe four 
stages, three with a clear relationship between both variables, and just one with special features (2009-2012), thus:

i) 1995-2003: There was a stagnation of both manufacturing and non-manufacturing. In the case of manufacturing there was a decrease followed by a recovery to 1995 levels in 2003 and in nonmanufactuirng there was slight stagnation with a minor positive trend.

ii) 2003-2009: There was an increase of manufacturing with a clear positive effect on nonmanufacturing.

iii) 2009-2013: There was an increase in non-manufacturing in spite of a decrease in manufacturing. This situation is usually unsustaineable, unless there are special circumstances that contribute to the sustainable development of services without excessively increasing the external trade deficit. Those special circumstances may include an increase in production in industries other than manufacturing (energy, for example) or there may be an increase in foreign tourism, income from abroad or other factors that contribute to an increase in the capacity to import without increasing the external trade deficit. In the years 2012 and 2013, there was an significant decrease in the commercial trade balance.

iv) 2014-2016: during this period, there was a decrease of both variables.

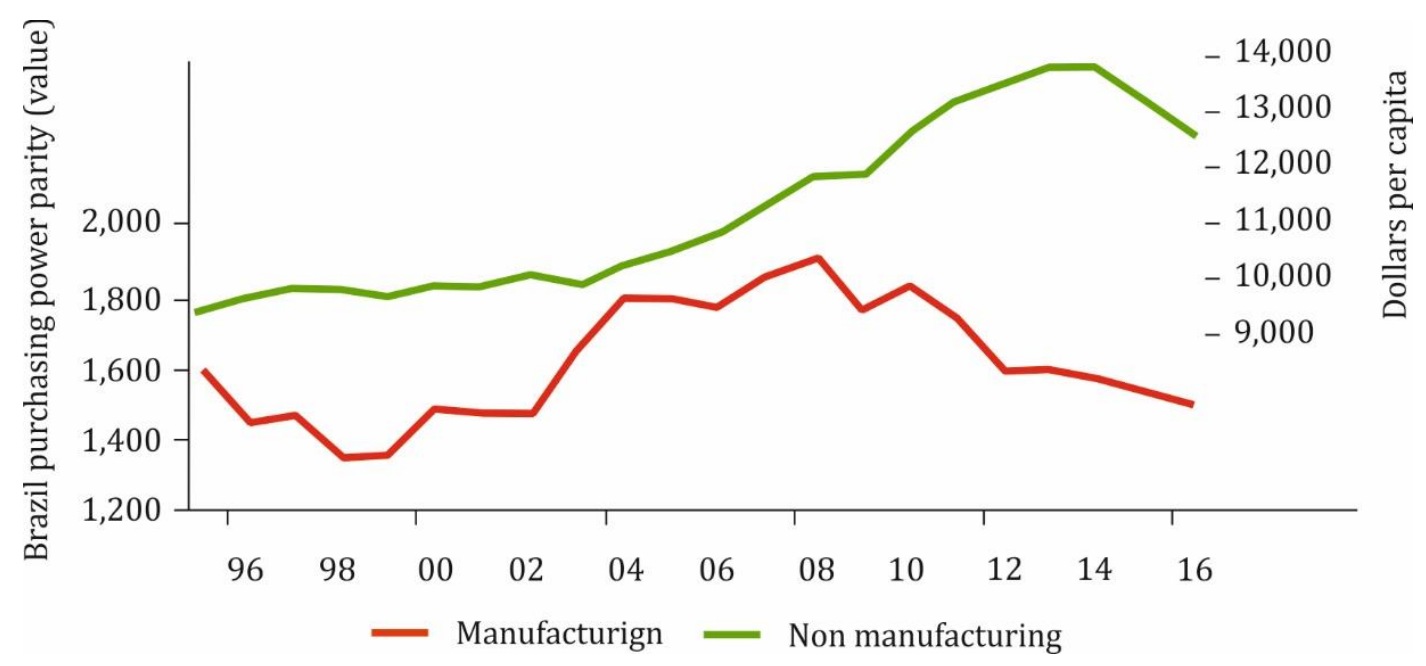

Figure 5. Real Value Added of the Manufacturing and Non-Manufacturing Sectors in Brazil 1995-2016 (Dollars per capita at 2011 prices and Purchasing Parities). Source: Guisán (2019): World Development Report 2019: America.

Guisán (2017) presents a comparison of real production per head in the world and reported that real value-added of manufacturing per capita is already low in Brazil, lower than both the US and world averages.

\section{Conclusions}

In Brazil, it may be observed that the performance of the economy has endured many oscillations throughout its history. In these terms, economic fluctuations must be taken into account, especially when we empirically estimate the effect of economic growth on inflation and the demographics of the country.

Nevertheless, the results of the research indicate that in recent decades emerging countries have presented product growth rates greater than those of developed countries, to the point that 
the gap between the latter and the former has diminished, although in a very precise manner in Brazil.

From an historical viewpoint, it may be observed that the recent performance of the Brazilian economy has oscillated between brief periods of economic growth and others of recession. The resumption of real GDP growth since 2003 was not accompanied by a robust growth trend in potential GDP.

Thus, in times of real GDP growth, this deviates little from the potential GDP to keep the inflation rate at a relatively low level. In any case, the timid economic growth policy of effective GDP is constrained due to fears of inflation speculation, although the gap indicates sluggish capacity.

Consequently, in order for the state of Brazilian development to escape the reckless stop go policy, in order to react more easily, it is necessary to carry out structural reforms, particularly fiscal reform, in order to allow the state to recover its fiscal-financial capacity to fund strategic investments in basic social capital, especially in transport infrastructure, ports and electricity.

The current moment indicates that Brazil needs to break this market, thus it is imperative that the economy grows again. There is no other option for reducing unemployment in Brazil. It is therefore essential for the federal government: to foster public and private investment so that all sectors of the economy may break with this current recession, maintaining inflation control mechanisms; to reduce the risk factor and uncertainty of investors/entrepreneurs so that they are encouraged to hire (more) labor, improving the reach of social protection systems for low-income families; and, especially, tocreate opportunities for the improvement and specialization of certain productive activities so that the country may create skilled labor, thus stimulating an increase in the income and consumption of these future workers.

It is important to note that while inflation is a relevant factor in certain aspects, especially in the Brazilian economy,, it is not the determining factor for economic growth and development. Moreover, in an economy where private investment spending has fallen significantly and there are no expectations of reversal, at least in the short term, government investment may help to break this inertia. Therefore, government administration - at federal, state and municipal levels - needs to foster public and private investment so that all sectors of the economy can cope with this current scenario of low economic dynamism, especially in stimulating the growth of formal work, and consequently of consumption.

Finally, it is also necessary to complete structural reforms with a clear definition of stable regulatory frameworks to increase the competitiveness of Brazilian companies and to provide openings for cooperation in public-private partnerships.

\section{Bibliography}

Bacha, E. L. (1998). O Plano Real: uma avaliação. In A. Mercadante (Ed.), Brasil Pós-Real: a política econômica em debate. Campinas, SP: UNICAMP.

Brum, A. J. (2012). O desenvolvimento econômico brasileiro. 28nd. ed. Petrópolis, RJ: Vozes.

Bresser-Pereira, L. C., \& Nakano, Y. (1991). Resíduo inflacionário, pós-congelamento e política monetária. In C. de Faro (Ed.), A economia Pós Plano Collor II (pp. 149-157). Rio de Janeiro, RJ: Livros Técnicos e Científicos.

Carneiro, R., \& Buainain, A. (Eds.). (1989). O retorno da ortodoxia. São Paulo, SP: Bienal-Unicamp.

Carneiro, D. D., \& Modiano, E. (1992). Ajuste externo e desequilíbrio interno: 1980-1984. In M. de Paiva Abreu \& D. Dias Carneiro (Eds.), A ordem do progresso: Cem anos de política econômica republicana, 1889-1989. Rio de Janeiro, RJ: Campus.

Carvalho, D. F., \& Carvalho, A. C. (2018). Crescimento econômico endógeno e convergência da renda per capita dos municípios do Estado do Pará: 1970-2000. In L. M. da Frota Carleial, B. de Oliveira Cruz \& E. Castro (Eds.), O desenvolvimento regional brasileiro: questões em debate (pp. 210-242). São Paulo, SP: Hucitec Editora.

Carvalho, A. C., \& Carvalho, D. F. (2019). Econometric models of inflation in Brazil: Structuralists, monetarists and rational expectations approaches, 1995-2017. Applied Econometrics and International Development, 19(2). Retrieved from http://www.usc.es/economet/eaat.htm 
Guisán, M. C. (2017). Manufacturing and economic development in the world for 2000-2015: Main features and challenges. Revista Galega de Economía, 26(3), 73-98. Retrieved from http://www.usc.es/revistas/index.php/rge/article/view/4482

Guisán, M. C. (2019). World development report 2019: America. Regional and Sectoral Economic Studies, 19(2). Retrieved from http://www.usc.es/economet/eaat.htm

Guisán, M. C., \& Cardim-Barata, S. (2003a). Industria y desarrollo regional en Brasil. Estudios Económicos Regionales y Sectoriales, 3(1), 25-48. Retrieved from

Guisán, M. C., \& Cardim-Barata, S. (2003b). Indústria e comércio externo na economia do Brasil, 1960-2000. Working Papers Series Economic Development, 73. Retrieved from http://www.usc.es/economet/eaat.htm

Instituto Brasileiro de Geografia e Estatística [IBGE]. IBGE/Sistema Nacional de Índices de Preços ao Consumidor (INPC-IPCA). Instituto Brasileiro de Geografia e Estatística-Séries Históricas. Rio de Janeiro, RJ: IBGE. Retrieved from https://ww2.ibge.gov.br/home/estatistica/indicadores/precos/inpc ipca/defaultseriesHist.shtm

Instituto de Pesquisa Econômica Aplicada [IPEAdata]. IPEAdata macroeconômico. Retrieved from http://www.ipeadata.gov.br/Default.aspx

Lago, L. A. C. do. (1992). A retomada do crescimento e as distorções do "milagre": 1967-1973. In M. de Paiva Abreu \& D. Dias Carneiro (Eds.), A ordem do progresso: Cem anos de política econômica republicana, 18891989. Rio de Janeiro, RJ: Campus.

Malan, P. (1999). Brasil: três finais de década. In J. P. de Almeida Magalhães, A. dos Santos Mineiro \& L. A. El'çias (Eds.), Vinte anos de política econômica. Rio de Janeiro, RJ: Contraponto.

Mantega, G. (2003). A nova estratégia de crescimento sustentado. In J. P. dos Reis Velloso (Coord.), Governo Lula: novas prioridades e desenvolvimento sustentado. Rio de Janeiro, RJ: José Olympio.

Pinheiro, A. C., Giambiagi, F., \& Gostkorzewicz, J. (1999). O desempenho macroeconômico do Brasil nos anos 90. In F. Giambiagi \& M. Mesquita Moreira (Eds.), A economia brasileira nos anos 90. Rio de Janeiro, RJ: BNDES.

Tavares, M. C., \& Carneiro, R. (1986). Política econômica da Nova República. Rio de Janeiro, RJ: Paz e Terra. 